\title{
ERRATA 3
}

No artigo "Estudo Experimental do Falar em Público Com e Sem Plateia em Universitários”, com número de DOI: 10.1590/1413-82712018230213, publicado no periódico Psico-USF, 23(2): 347-359, nas páginas 347 e 359:

Onde se lia: "Arthur Keller Andrade"

Leia-se: "Arthur Kelles Andrade" 